International Journal of Biodiversity Science, Ecosystem Services \& Management

\title{
Tree species diversity and abundance in coffee farms adjacent to areas of different disturbance histories in Mabira forest system, central Uganda
}

\author{
Samson Gwali, Hillary Agaba, Paul Balitta, David Hafashimana, Joseph
} Nkandu, Anne Kuria, Fabrice Pinard \& Fergus Sinclair

To cite this article: Samson Gwali, Hillary Agaba, Paul Balitta, David Hafashimana, Joseph Nkandu, Anne Kuria, Fabrice Pinard \& Fergus Sinclair (2015): Tree species diversity and abundance in coffee farms adjacent to areas of different disturbance histories in Mabira forest system, central Uganda, International Journal of Biodiversity Science, Ecosystem Services \& Management, DOI: 10.1080/21513732.2015.1050607

To link to this article: http://dx.doi.org/10.1080/21513732.2015.1050607

View supplementary material $₫$

Published online: 17 Jun 2015.

Submit your article to this journal $\pi$

Џ Article views: 32

View related articles

View Crossmark data $₫$ 


\title{
Tree species diversity and abundance in coffee farms adjacent to areas of different disturbance histories in Mabira forest system, central Uganda
}

\author{
Samson Gwali ${ }^{\text {a*}}$, Hillary Agaba ${ }^{\mathrm{b}}$, Paul Balitta ${ }^{\mathrm{c}}$, David Hafashimana ${ }^{\mathrm{d}}$, Joseph Nkandu ${ }^{\mathrm{e}}$, Anne Kuria ${ }^{\mathrm{f}}$, Fabrice Pinard $^{\mathrm{g}}$ \\ and Fergus Sinclair ${ }^{\mathrm{f}}$
}

${ }^{a}$ Tree Improvement and Germplasm Research Programme, National Forestry Resources Research Institute (NaFORRI), P.O. Box 1752, Kampala, Uganda; ${ }^{b}$ Agroforestry Research Programme, National Forestry Resources Research Institute (NaFORRI), P.O. Box 1752, Kampala, Uganda; ${ }^{c}$ Forest Products and Services Research Programme, National Forestry Resources Research Institute (NaFORRI), P.O. Box 1752, Kampala, Uganda; ${ }^{d}$ Conservation and Ecology, Bulindi Zonal Agricultural Research and Development Institute (BuZARDI), P.O. Box 101, Hoima, Uganda; ${ }^{\circ}$ Coffee Production and Quality, National Union of Coffee Agribusinesses and Farm Enterprises (NUCAFE), P.O. Box 34967, Kanmpala, Ugada, ${ }^{f}$ Agroforestry Systems Science Domain, World Agroforestry Centre, ICRAF, P.O. Box 30677, 00100 Nairobi, Kenya; ${ }^{g}$ Système Biologiques (BIOS), UPR Bioagresseurs, Centre de Coopération Internationale en Recherche Agronomique pour le Développement (CIRAD), Avenue Agropolis, 34598 Montpellier, Cedex, France

(Submitted 22 April 2014; accepted 8 May 2015; edited by Patricia Balvanera)

\begin{abstract}
Coffee production in Uganda is done on small-scale farms containing a very significant tree component. However, there is little information on how tree species abundance, richness and diversity change in coffee farms as distance from forest changes. The main objectives of this study, therefore, were to assess (a) abundance and (b) diversity of tree species in the coffee production systems in proximity to disturbed and undisturbed forest around Mabira forest, one of Uganda's Robusta coffee-growing areas. Seventy-nine 0.1 ha plots were established in nine villages close to undisturbed and disturbed forest, and over $5 \mathrm{~km}$ from the forest. A total of 875 trees belonging to 63 species were recorded. There was significant similarity in species composition among the three study sites (analysis of similarity $R=0.09, p<0.01$; analysis of variance: $F_{3,12}=0.353, p=0.79$ ). Non-metric dimensional scaling supported these findings (stress value $=0.224$ at $k=2$ ) and showed that tree species composition in the three proximity categories was very similar. These results demonstrate that tree species composition and diversity is similar in coffee farms regardless of their distance from the nearest natural forest and forest exploitation history.
\end{abstract}

Keywords: Robusta coffee; tree diversity; species richness; coffee farms; Mabira forest

\section{Introduction}

The practice of tree integration in coffee production systems plays a very important role in biodiversity conservation (Perfecto et al. 1996; Albertin \& Nair 2004; Rice 2008; Correia et al. 2010). Many local people, who are short of forest goods and services, introduce trees in agricultural landscapes (Arnold 1997). In Uganda, tree planting and conservation are common practices in the traditional farming systems (Boffa et al. 2008; Isabirye et al. 2008). For example, close to $50 \%$ of tree cover on farmed landscapes in the Kigezi highlands is composed of planted trees (Boffa et al. 2005), which suggests that farmers may be contributing to tree diversity conservation by actively planting trees in farms. In coffee farming systems, farmers maintain some indigenous and grow exotic tree species to minimize competition with coffee plants while helping to ameliorate climate changes, maintain soil fertility and provide important goods such as timber, fuel wood and fruit (Beer et al. 1997; Albertin \& Nair 2004; Bandeira et al. 2005; Soto-Pinto et al. 2007). These ecosystem goods and services help to lower the cost of production as well as diversify farm production and benefits (Beer et al. 1997; Peeters et al. 2003; Albertin \& Nair 2004; Soto-Pinto et al. 2007;
Méndez et al. 2007; Ipulet \& Kasenene 2008; Isabirye et al. 2008; Rice 2008).

In most cases, farmers themselves are aware of the contribution of trees as a buffer against poor yields, unpredictable markets, food shortages, fuel scarcity and as a source of medicinal treatment (Kasolo \& Temu 2008; Sebukyu \& Mosango 2012). These values are especially important to the small scale peasant farmers where there is need for diversification of farm products (Masiga \& Ruhweza 2007). Therefore, there is a lot of interest in integrating trees in agricultural systems (Balihuta \& Sen 2001; Bolwig et al. 2006; Masiga \& Ruhweza 2007).Coffee farming in Uganda is therefore practised in mixed stands that involve intercropping with trees and food crops, such as bananas and beans, which contribute to household food security (Place \& Otsuka 2000; Isabirye et al. 2008). Such management practices have been identified as a principal factor in determining tree diversity and presence of forest species in coffee farms (Perfecto \& Vandermeer 2002).

There has, however, been a long running debate of whether integration of trees for shade in coffee farms is really beneficial to the coffee plants and whether it has any impact on yield. In a groundbreaking publication, Lock (1888) stated that while shading may diminish coffee 
crop exhaustion and increase the longevity of coffee plants, it could also result in reduced coffee bean yield. Beer et al. (1997) noted that too much shading may lead to stiff ecological competition between coffee and shade plants. Shade has also been shown to influence populations of insect pests and prevalence of disease, and weeds (Beer et al. 1997; Perfecto et al. 1996) and depress yields (Escalante 1995; Muschler \& Bonnemann 1997; Soto-Pinto et al. 2000). In Central America, shade trees in coffee production systems have, however, been shown to improve nutrient cycling by absorbing nutrients through the roots at greater depths in the soil (Snoeck et al. 2000) and depositing leaf litter on the surface. Shade trees also reduce the growth of weeds and increase local biodiversity by providing food or shelter for many animal species (Perfecto et al. 2005; Rice 2008). In addition, there is growing evidence that tree shade positively affects coffee quality (Muschler 2001; Vaast et al. 2005; Méndez \& Bacon 2006; Bote \& Struik 2011). Vaast et al. (2006) demonstrated that although shade reduced coffee tree productivity by $18 \%$, it positively affected bean size and composition as well as beverage quality by delaying berry flesh ripening.

Tree diversity in coffee farms was often thought to decline with increasing distance from forest because dispersal and survival rates are lower in the lower-quality agricultural habitats and in areas that differ substantially from natural areas in terms of canopy cover and microclimate (Perfecto \& Vandermeer 2002; Ricketts 2004). While several studies have investigated the biodiversity in coffee agro-ecosystems, there has been little work on the diversity and abundance of trees within the coffee agro-ecosystems relative to the distance from forest. A fundamental complication arises from the fact that beta diversity (diversity relative to distance from forest) is calculated based on differences between sampling units (e.g. Legendre et al. 2005; Tuomisto and Ruokolainen 2006; Jost 2007). Therefore, there would be need to take farm size and management practice into account when calculating beta diversity of coffee farms. Several researchers have, however, specifically examined and found that animal diversity declines with distance from forest fragments (Ricketts et al. 2001; Banks et al. 2013). In one of a few related plant studies, Moorhead et al. (2010) found no significant change in species richness of epiphytes at different distances from forest in a coffee polyculture. Williams-Linera (2002) found higher species richness in diverse polycultures compared to surrounding coffee farms and attributed this to shift of tree species composition from one site to the next. Boffa et al. (2008) studied tree diversity in agricultural landscapes around Mabira forest using a series of transects radiating up to $20 \mathrm{~km}$ away from the forest edge and found that there was no significant differences at the 0.05 level in tree abundance and species richness between distance categories. Nevertheless, it is generally accepted that the conservation value of coffee farms is enhanced when they overlap with tropical forests (Hernández-Martínez et al. 2009).

This study aimed at assessing the abundance and diversity of tree species in the coffee production systems around Mabira Forest Reserve, one of the biggest Robusta coffee-growing areas of Uganda. Our specific objectives were to find out (a) whether closeness to natural forest influences tree species diversity in coffee farms, (b) whether there is any relationship in tree diversity between coffee farms close to disturbed forest (DF) and undisturbed forest (UDF) and (c) what the dominant tree species in coffee farms are. We did not seek to collect data on farmer management practices and species preferences that could be regulating the tree diversity in coffee farms since this was outside the scope of this study.

\section{Materials and methods}

\section{Study area}

This study was carried out in Buikwe, Nakifuma and Mukono counties of Mukono district in central Uganda (Figure 1). Mukono district is situated between $32^{\prime} 52^{\circ}-$ $33^{\prime} 07^{\circ} \mathrm{E}$ and $0^{\prime} 24^{\circ}-0^{\prime} 35^{\circ} \mathrm{N}$ at an altitudinal range of $1070-1340 \mathrm{~m}$ and covers an area of $14,241 \mathrm{~km}^{2}$ of which $9648 \mathrm{~km}^{2}$ is open water and swamps (Kamanyire 2000). The climate is influenced by Mabira Forest Reserve and lakes Kyoga and Victoria and the district experiences two rainy seasons (March to May and September to December), with a mean annual rainfall of $1400-1600 \mathrm{~mm}$ but as high as $1600-2000 \mathrm{~mm}$ in areas close to the lakes and forest reserve (NEMA 1997). The district is dominated by small-scale subsistence agriculture largely dependent on human labour and the use of simple tools such as hoes and machetes (Katumba et al. 2004). Robusta coffee is grown especially in the predominant coffee-banana system in the southern part of the district (NEMA 1997).

\section{Sampling and data collection}

The study sites (villages) were stratified to represent coffee farms close to DF, UDF, at least $5 \mathrm{~km}$ away from the forest margin (FF) and one large commercial coffee estate (CF) located at least $5 \mathrm{~km}$ from the forest margin (Table 1). In the context of this study, DF refers to a forest area which is regenerating after large-scale timber harvesting and other anthropogenic disturbances. On the other hand, UDF refers to intact natural forest which has remained essentially unmodified by human activity for the last 60-80 years.

A total of seventy-nine $50 \mathrm{~m} \times 20 \mathrm{~m}(0.1 \mathrm{ha})$ plots were systematically established in nine villages. In each village, the plots were established at $100 \mathrm{~m}$ intervals in alternating succession along either side of a $3 \mathrm{~km}$ transect. The number of plots established per category varied (23 plots close to DF; 27 plots close to UDF; 26 plots far from forest; and three plots in the coffee estate, far from the forest) (Table 1). All trees with at least $10 \mathrm{~cm}$ diameter at breast height were enumerated and taxonomically identified with the help of a botanist on the research team. All plots were geo-referenced with the aid of a global positioning system. 


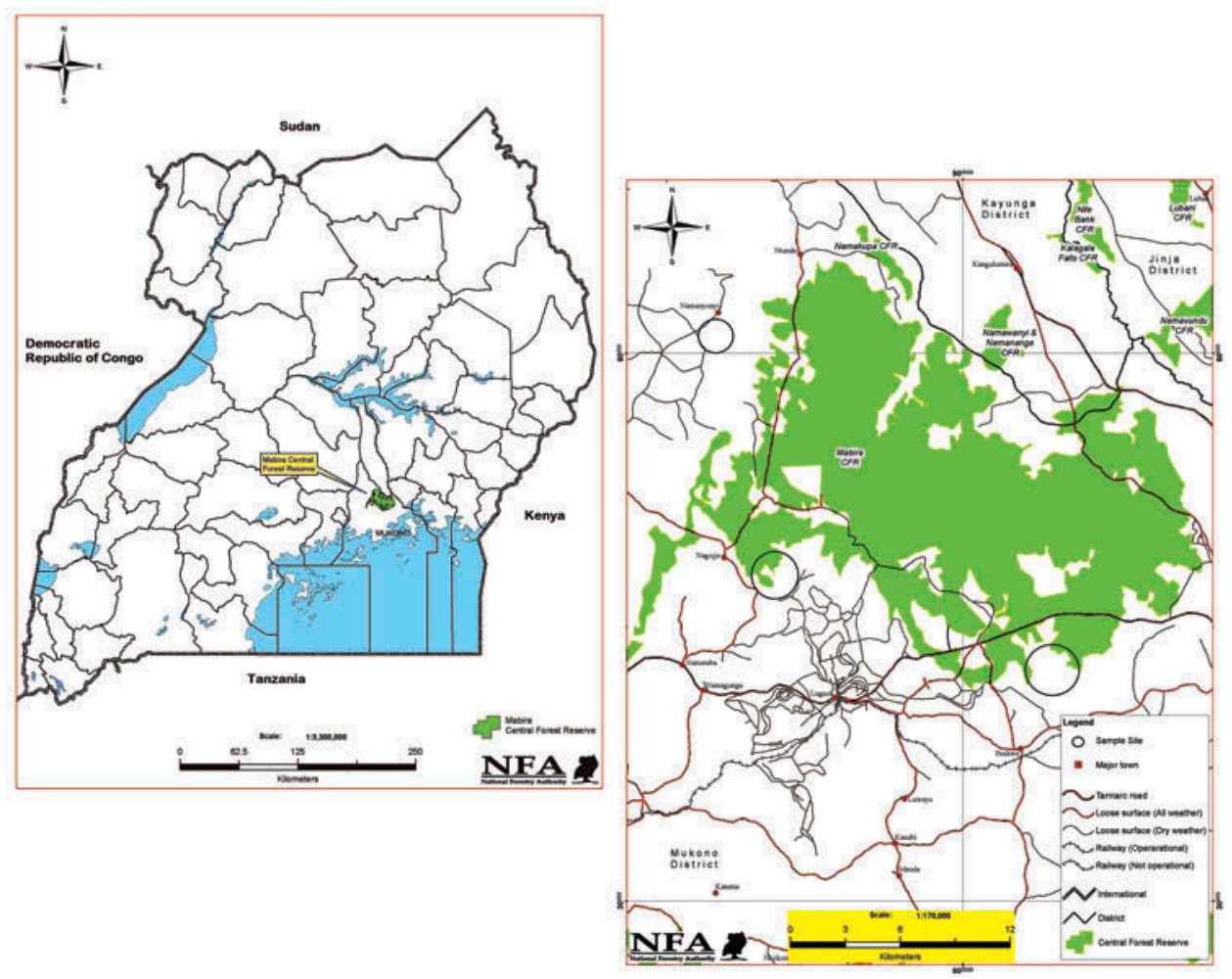

Figure 1. Map of Uganda (left) showing location of Mabira forest in central Uganda. To the right is a map of Mabira forest showing the sampling locations (circles).

Table 1. Villages and number of plots sampled in different coffee farms.

\begin{tabular}{|c|c|c|c|c|}
\hline County & Subcounty & Village & $\begin{array}{c}\text { Forest } \\
\text { proximity }\end{array}$ & $\begin{array}{l}\text { No of } \\
\text { plots }\end{array}$ \\
\hline \multirow[t]{3}{*}{ Buikwe } & \multirow[t]{3}{*}{ Najjembe } & Bulyasi & $\mathrm{DF}(<3 \mathrm{~km})$ & 9 \\
\hline & & Kinoni Central & $\mathrm{DF}(<1 \mathrm{~km})$ & 7 \\
\hline & & $\begin{array}{l}\text { Kinoni } \\
\text { Kidadiri }\end{array}$ & $\mathrm{DF}(<2 \mathrm{~km})$ & 7 \\
\hline \multirow[t]{4}{*}{ Nakifuma } & \multirow[t]{4}{*}{ Kimenyedde } & Mayangayanga & $\mathrm{FF}(>5 \mathrm{~km})$ & 9 \\
\hline & & Kawongo & $\mathrm{FF}(>5 \mathrm{~km})$ & 14 \\
\hline & & Kimenyedde & $\mathrm{FF}(>5 \mathrm{~km})$ & 3 \\
\hline & & Kondogoro & $\mathrm{CF}(>5 \mathrm{~km})$ & 3 \\
\hline \multirow[t]{2}{*}{ Mukono } & \multirow[t]{2}{*}{ Ntenjeru } & Butinindi & $\begin{array}{l}\mathrm{UDF} \\
(<1 \mathrm{~km})\end{array}$ & 5 \\
\hline & & Terere & $\begin{array}{l}\text { UDF } \\
\qquad(<1 \mathrm{~km})\end{array}$ & 22 \\
\hline
\end{tabular}

Note: DF, coffee farms close to relatively disturbed forest; FF, coffee farms over $5 \mathrm{~km}$ from the forest margin; $\mathrm{CF}$, large commercial coffee estate; UDF, coffee farms close to relatively undisturbed forest.

\section{Data analysis}

Tree species diversity and evenness ordering was performed by computing Rènyi diversity profiles at 1000 permutations and determining the species richness $(S)$, Shannon diversity index $(H)$ and Simpson diversity index $\left(D^{-1}\right)$ from the $H_{\alpha}$ values. To compare species diversity across forest proximity categories, individual-based species richness curves were computed using the software
PAST version 2.17c (Hammer et al. 2001). The species abundance and distribution between the different forest proximity categories were compared using analysis of similarities (ANOSIM) based on Bray-Curtis dissimilarity distances at 1000 permutations. A one-way analysis of variance (ANOVA) was also performed using the values of tree abundance, species richness, Shannon and Simpson diversity to test whether the differences observed between the proximity categories were statistically significant. To assess the tree diversity and abundance community distance between the three proximity categories, we used the non-metric multidimensional scaling (NMDS). An NMDS assigns each site (represented by a point) to a specific location in a conceptual low-dimensional space such that the distances between points in the space represent the given similarities between sites as closely as possible. The input distance matrix was based on a Bray-Curtis index calculated between each proximity category. Except for computation of species richness curves, all statistical computations were performed using BiodiversityR software (Kindt \& Coe 2005) building on the free R 3.0.2 statistical programme and its contributing packages.

\section{Results}

\section{Tree species abundance and composition}

A total of 875 trees belonging to 63 species and 29 families were encountered. The average stem density of 
trees on coffee farms was 110 stems per hectare. Twenty families encountered had only a single species. Moraceae was the largest family with 13 species while Fabaceae and Euphorbiaceae had 7 and 6 species, respectively. While some trees which were recorded can be categorized as exotic and have adapted successfully to local site conditions, indigenous trees accounted for $65 \%$ of the total number of species recorded (41 out of 63 ). In addition, $52 \%$ (or 33 of the 63 ) of the species recorded also occurred inside Mabira forest, comparing closely with a similar study by Boffa et al. (2008) who recorded $46 \%$ of woody species that occurred both in Mabira forest and surrounding coffee farms. There were no species in the coffee farms that can be considered endemic to Mabira forest. Over $45 \%$ of the species recorded can be described as forest dependent while 39\% can be described as forest non-dependent according to the classification of Davenport et al. (1996).

The most abundant trees in the coffee farms were shown to be fruit trees (434 trees representing 50\% of all trees recorded). The 10 most abundant tree species encountered had 707 trees; which accounted for over $80 \%$ of the total tree counts, while the top four species (representing $6 \%$ of the total number of species encountered) contained $54 \%$ of all the trees counted. These were Artocarpus heterophyllus (Moraceae), Carica papaya (Caricaceae), Albizia chinensis (Fabaceae) and Persea americana (Lauraceae) (Figure 2). Forty-two per cent of the species encountered were singletons. Most of these were indigenous forest trees species.

Farms farthest away from the forest (FF) had the highest average tree density (120 trees per hectare, 73 exotic and 47 indigenous trees), followed by farms close to DF (116 trees per hectare; 85 exotic and 31 indigenous trees), and the lowest tree density was in farms close to

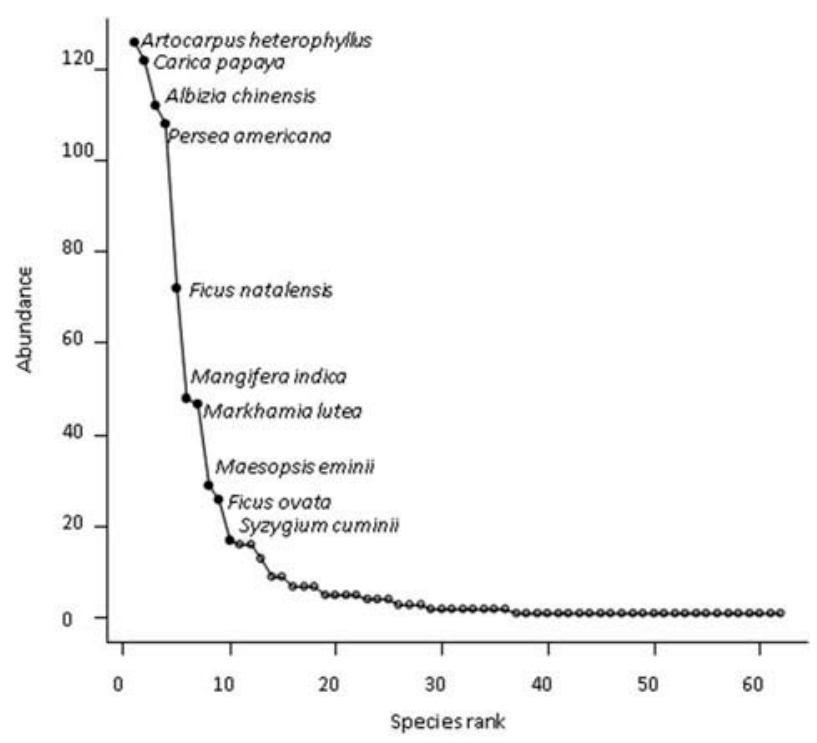

Figure 2. Tree species abundance curve (all coffee farms pooled together; names of 10 most abundant species).
Table 2. Ranking of the 10 most abundant species in the three forest proximity categories (excluding the coffee estate).

\begin{tabular}{lccccc}
\hline Species & Origin & $\mathrm{Rd}$ & $\mathrm{RF}$ & $\mathrm{RD}$ & $\mathrm{IVI}$ \\
\hline Artocarpus heterophyllus & Naturalized & 14.4 & 12.1 & 1.7 & 9.4 \\
Carica papaya & Naturalized & 14.0 & 11.4 & 0.8 & 8.7 \\
Persea americana & Naturalized & 12.4 & 9.9 & 0.8 & 7.7 \\
Albizia chinensis & Naturalized & 12.8 & 7.2 & 2.5 & 7.5 \\
Ficus natalensis & Indigenous & 8.2 & 7.7 & 2.2 & 6.0 \\
Mangifera indica & Naturalized & 5.5 & 6.2 & 2.2 & 4.6 \\
Markhamia lutea & Indigenous & 5.4 & 5.7 & 0.7 & 3.9 \\
Ficus ovata & Indigenous & 3.0 & 3.7 & 2.9 & 3.2 \\
Maesopsis eminii & Indigenous & 3.3 & 4.0 & 1.3 & 2.8 \\
Milicia excelsa & Indigenous & 1.8 & 2.7 & 3.0 & 2.5 \\
\hline
\end{tabular}

Note: Rd, relative density; RF, relative frequency; RD, relative dominance; IVI, importance value index.

UDFs (94 trees per hectare, 58 exotic and 36 indigenous trees). The coffee estate, however, had the highest tree density (140 trees per hectare) comprising only two species, namely $A$. chinensis and Maesopsis eminii. The 10 most abundant tree species in each forest proximity category were dominated by exotic fruit trees and are shown in Table 2. The importance value indices showed that $A$. heterophyllus, C. papaya, P. americana, A. chinensis and Ficus natalensis were the five most important species. Although A. chinensis was more abundant in coffee farms (IVI $=7.5)$ compared to $F$. natalensis $(\mathrm{IVI}=6.0)$ in terms of abundance, $F$. natalensis $(\mathrm{RF}=7.6 \%)$ was encountered more frequently than $A$. chinensis $(\mathrm{RF}=7.1 \%)($ Table 2$)$.

\section{Tree species diversity (richness and evenness)}

Farms close to UDFs had the highest species richness (39 tree species), followed by farms far from (FF) forest boundary (over $5 \mathrm{~km}$ from) which had 38 species while farms close to DFs had the lowest species richness of 26 species (Figure 3a). When analysed on the basis of species per forest proximity category and species origin (Figure $3 \mathrm{~b}$ and c), farms far from forest had the highest exotic species richness (15 species) followed by farms adjacent to UDF (13 species). In terms of indigenous tree species richness, farms adjacent to UDF have the highest species richness (26 species) followed by farms far from forest (23 species). However, the species accumulation curve for indigenous trees (Figure 3b) indicated that more species would be found with more sampling. Rènyi diversity profile showed that farms close to the UDF had the highest species diversity, but we could not order diversity for farms close to DF and farms far from forest because they intersected (Figure 4a). On the other hand, Rènyi evenness profiles intersected hence we could not rank the three forest proximity categories based on tree counts from the least to the most evenly distributed (Figure 4b). Multidimensional scaling revealed that the clusters for UDF, FF and DF overlap to a greater extent (Figure 5), indicating that tree community composition among the 

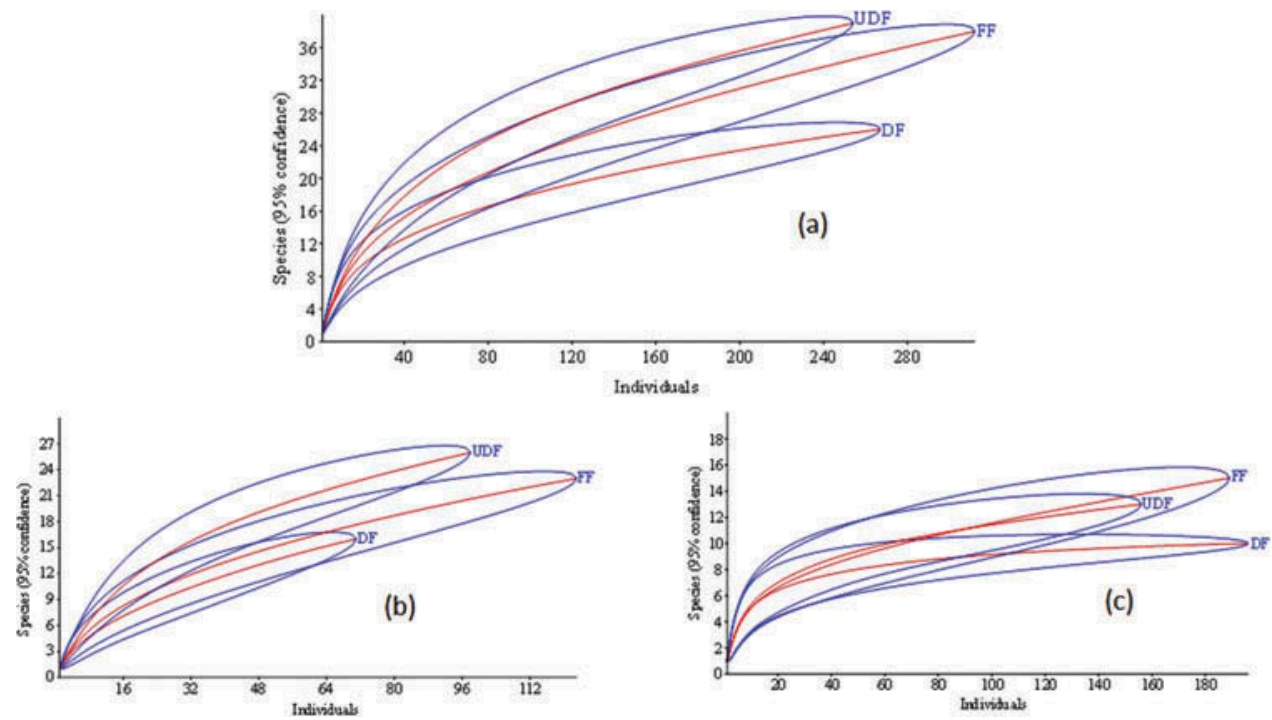

Figure 3. Individual-based rarefaction curves for all species (a), indigenous species (b) and exotic species (c) in the coffee agroforests under different proximity distances to natural forest (UDF, coffee farms close to relatively undisturbed forest; FF, coffee farms over $5 \mathrm{~km}$ from the forest margin; DF, coffee farms close to relatively disturbed forest).
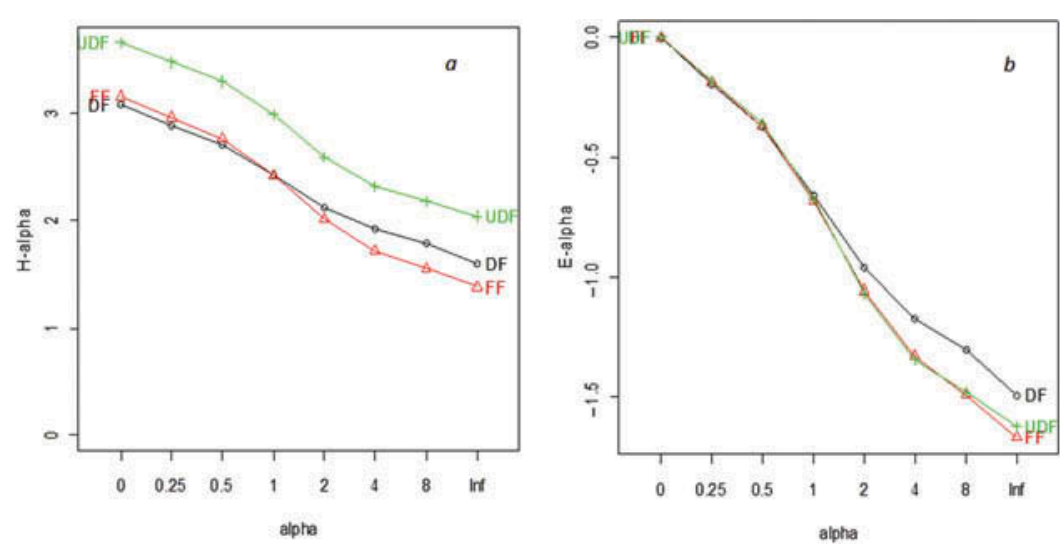

Figure 4. Rènyi diversity (a) and Rènyi evenness (b) profiles for the three forest proximity categories (UDF, coffee farms close to relatively undisturbed forest; $\mathrm{FF}$, coffee farms over $5 \mathrm{~km}$ from the forest margin; DF, coffee farms close to relatively disturbed forest).

sample plots in the different proximity categories not readily distinguishable into two dimensions as evidenced by the stress values of 0.224 at $K=2$. Final stress values should ideally be smaller than 0.1 (Zuur et al. 2007) and not larger than 0.3 to represent species abundance data accurately (Kindt \& Coe 2005). The tree diversity and abundance in the large coffee estate (CF), however, strongly differed and was separated from the rest of the proximity categories in the NMDS ordination. Thirty-three $(52 \%)$ of all species recorded in this study are also found in Mabira forest. Species such as Entada abyssinica and Steganotaenia araliacea have been recorded as woodland tree species (Davenport et al. 1996). A number of forest non-dependent and forest generalists were also recorded on coffee farms. These included Albizia coriaria, Antiaris toxicaria, Bridelia micrantha and others among the forest non-dependent species; and Alstonia boonei, Canarium schweinfurthii, Croton macrostachys and others among the forest generalist species (see Supplementary material). A comparison of species abundance, richness and diversity showed very low variation between the three forest proximity categories (ANOSIM $R$ : $0.09029, p=0.001$ based on Bray-Curtis distances using 1000 permutations; ANOVA: $\left.F_{3,12}=0.353, p=0.79\right)$. Coffee farms close to UDF had more species (Shannon $H^{\prime}=2.988$, Simpson $D=0.926$ ) compared to farms close to DF (Shannon $H^{\prime}=2.482$, Simpson $D=0.887$ ) (Table 3; see also Figure 5). Farms further away from the forest margin (FF) were comparable in species richness to those near UDF. Rarefied species accumulation curves (Figure 3) indicate that more sampling would record higher species diversity than is reported in the present study. 
Table 3. Comparison of species richness, tree abundance and diversity among the coffee farms.

\begin{tabular}{|c|c|c|c|c|c|c|c|c|c|c|c|c|c|c|c|c|c|c|c|c|c|}
\hline \multirow{2}{*}{$\begin{array}{l}\text { Proximity to } \\
\text { forest }\end{array}$} & \multirow{2}{*}{$\begin{array}{l}\text { No of } \\
\text { plots }\end{array}$} & \multicolumn{5}{|c|}{ Stem abundance $(A)$} & \multicolumn{5}{|c|}{ Richness $(S)$} & \multicolumn{5}{|c|}{ Shannon diversity $\left(H^{\prime}\right)$} & \multicolumn{5}{|c|}{ Simpson diversity $(D)$} \\
\hline & & $A$ & Mean & SD & Max & Min & $S$ & Mean & SD & $\operatorname{Max}$ & Min & $H^{\prime}$ & Mean & SD & Max & Min & $D$ & Mean & SD & $\operatorname{Max}$ & Min \\
\hline $\begin{array}{l}\text { Commercial } \\
\text { farm }\end{array}$ & 3 & 42 & 14.00 & 2.00 & 16 & 12 & 2 & 1.33 & 0.58 & 2 & 1 & 0.110 & 0.09 & 0.15 & 0.26 & 0.00 & 0.046 & 0.04 & 0.08 & 0.13 & 0.00 \\
\hline $\begin{array}{l}\text { Disturbed } \\
\text { forest }\end{array}$ & 23 & 267 & 11.61 & 5.82 & 26 & 3 & 26 & 5.22 & 2.11 & 9 & 2 & 2.482 & 1.38 & 0.43 & 2.00 & 0.64 & 0.887 & 0.68 & 0.14 & 0.84 & 0.41 \\
\hline $\begin{array}{l}\text { Far from forest } \\
\quad>5 \mathrm{~km}\end{array}$ & 26 & 312 & 12.00 & 6.44 & 31 & 4 & 38 & 5.58 & 1.96 & 10 & 3 & 2.781 & 1.48 & 0.32 & 2.06 & 0.95 & 0.910 & 0.73 & 0.08 & 0.86 & 0.55 \\
\hline $\begin{array}{l}\text { Undisturbed } \\
\text { forest }\end{array}$ & 27 & 254 & 9.41 & 4.53 & 18 & 2 & 39 & 5.07 & 2.09 & 10 & 1 & 2.988 & 1.39 & 0.47 & 2.10 & 0.00 & 0.926 & 0.69 & 0.19 & 0.86 & 0.00 \\
\hline
\end{tabular}

Note: $H^{\prime}$, Shannon; $S$, Simpson diversity indices; CF, large commercial coffee farm $>5 \mathrm{~km}$ from forest; UDF, coffee farms close to relatively undisturbed forest; FF, coffee farms over $5 \mathrm{~km}$ from the forest margin; DF, coffee farms close to relatively disturbed forest.

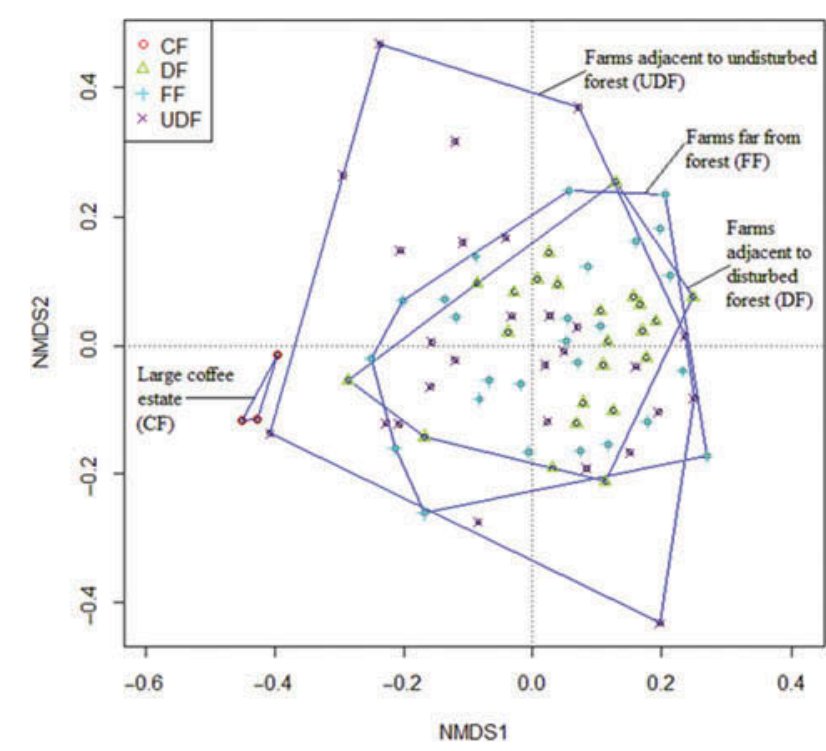

Figure 5. Non-metric dimensional scaling of tree abundance on coffee farms in the three proximity categories including large coffee estate (UDF, farms adjacent to undisturbed forest; $\mathrm{DF}$, farms adjacent to disturbed forest; $\mathrm{FF}$, farms far from forest). The stress value is 0.224 at $K=2$. Points represent tree species abundance calculated with the Bray-Curtis similarity index.

\section{Discussion}

Most coffee in Uganda is cultivated by small holder farmers, often in farms between 0.5 and 2.5 ha in size (Kamanyire 2000; Bolwig et al. 2006). Farmers therefore integrate a diversity of tree species on these small farms in order to diversify their outputs. Although over $52 \%$ of the trees found in coffee farms are also found in Mabira forest, our results show a high tree cover in coffee farms, in concordance with similar studies (cf. Boffa et al. 2008). The average tree density (110 trees per hectare) that has been shown in this study is higher than that observed in Nigeria where 91 trees per hectare were recorded in farmed landscapes (Gobin et al. 2001), while Isabirye et al. (2008) recorded 96 trees per hectare and 90 trees per hectare over perennial crops in farmed landscapes in Rakai and Mayuge districts of Uganda, respectively. The tree density reported in the present study is, however, much lower than that reported in Central America. Rice (2008) reported a density of 135 trees per hectare in Peru and 163 trees per hectare in Guatemala. This could be due to the relatively higher tree diversity and tree intensification in the coffee farms of Central America (Rice 2008) compared to Africa (Gobin et al. 2001; Isabirye et al. 2008). The low levels of tree intensification in coffee farms around Mabira forest may also be due to the higher temperature requirements $\left(22-30^{\circ} \mathrm{C}\right)$ of Robusta coffee compared to Arabica coffee $\left(18-22^{\circ} \mathrm{C}\right)$ (Pohlan \& Janssens 2012). In addition, it has been noted that Robusta coffee has a more developed root system and is more vigorous in growth compared to Arabica (DaMatta \& Ramalho 2006; DaMatta et al. 2007) and hence competition between coffee and shade trees would be higher in the Robusta-growing areas.

The most dominant tree species in the coffee farms were shown to be fruit trees. These trees are mainly planted and/or retained for income, nutrition and as a buffer for the ever present vicissitudes that face the coffee sector in Uganda. The coffee sector is just revitalising after the fall in coffee prices between 2011 and 2013 (International Coffee Council 2014) which caused many farmers to shift to vanilla production. Presently, Robusta coffee production in Uganda is seriously grappling with the coffee wilt disease that has greatly affected production. In spite of these predicaments, with the cultural attachment to coffee in this region, farmers tend to diversify farm production (while retaining coffee production at all times). Therefore, the presence of many fruit trees in the coffee gardens is a deliberate intensification strategy. Fruit tree products are in very high demand, especially in the neighbouring urban centres of Kampala, Entebbe, Jinja and Mukono (Kamanyire 2000; Baranga 2007). Such is the demand that farmers are able to sell their products from the farm without incurring expenses for transportation to the markets.

All farms in the three proximity categories exhibited a high and consistent proportion of exotic compared to indigenous species. Apart from some trees that are also planted for fruit, there is a high abundance of trees that are planted mainly for coffee shade such as $A$. chinensis. This 
species is not only a good shade tree (Sanchez et al. 1988; Kiyingi \& Gwali 2012) but fixes nitrogen and is also a fast-growing timber tree. In addition, there are some indigenous trees that farmers plant or sometimes deliberately retain in coffee farms to provide shade but also to obtain other intermediate products such as firewood and poles. These include Ficusspp., Markhamia lutea, M. eminii, Cordia africana and Milicia excelsa. Species such as $M$. lutea can be harvested for poles, $M$. excelsa for timber, $C$. africana for boat construction wood and $F$. natalensis for bark cloth. In the central region of Uganda, the bark of $F$. natalensis is used to make a cultural cloth called 'olubugo' that is used in a range of rituals such as funerals, succession and naming (Ipulet \& Kasenene 2008). F. natalensis profusely regenerates through seed and vegetatively and is therefore widely planted and retained on farm. This explains the apparently high frequency of $F$. natalensis in coffee farms around Mabira forest compared to other planted species like $A$. chinensis (Table 2).

Among the 10 most abundant tree species encountered, 8 are exotic species. Moreover, there is a high percentage of singletons (many of them being indigenous species) probably due to the limited dispersal of rainforest tree species (Terborgh et al. 2002). It is also possible that the limited number of indigenous species is caused by selective cutting and removal of unwanted trees by farmers. It is worth noting that tree management regimes and planting in this area are strongly influenced by the land tenure system. In central Uganda, most land is governed under the 'Mailo' tenure system where landlords own vast areas of land while the rest of the population use the land as tenants or 'Kibanja holders' (Kigula 1993; Place \& Otsuka 2000). Other land tenure systems in central Uganda include the freehold, mailo land and leasehold (Place \& Otsuka 2000). Tree tenure rights especially for the more widespread mailo land system are unclear with the tenants usually restricted to usufruct rights over particular tree species. Long rotation trees such as $M$. excelsa are not usually planted in land where one is only a tenant. Planting such species can be construed as an attempt to take over land ownership, a gesture that does not go down well with many 'mailo' land owners. Therefore, farmers tend to plant quicker maturing tree species such as fruit trees and the fast-growing $A$. chinensis as shade trees in coffee farms (Table 3).

With the exception of coffee farms close to the UDF where some forest species occur, the composition of tree species is not significantly different among the three forest proximity categories (see Figure 5). This may indicate similarity in the importance of these species to farmers across the three proximity categories. Boffa et al. (2008) studied tree diversity in agricultural landscapes around Mabira forest and found a similar pattern. This result also compares to that of Abebe (2005), who reported that proximity to roads significantly influenced tree diversity in home garden agroforestry systems on account of the greater demand and access to wood products. Such high proportions of indigenous species in coffee plantations are undoubtedly a reflection of farmers' intimate knowledge of their characteristics and potential uses (Soto-Pinto et al. 2007), as well as their enhanced availability due to seed dispersion and natural establishment (Bandeira et al. 2005; Méndez et al. 2007), and the fact that they are better adapted to local climatic conditions (Albertin \& Nair 2004). Farmers will plant and conserve on farm any species that they believe is important to them. There is, however, need for more research to establish the optimum shade level that favours higher coffee yields, coffee quality and boosts coffee tree resistance to adverse weather conditions, pests and diseases.

\section{Conclusion}

Coffee farms have the potential to maintain a diversity of tree species outside natural forests. Tree species diversity was higher in farms close to UDFs, followed by farms far from the forest margin and the lowest diversity was recorded in farms close to DFs. The highest tree abundance was recorded for the areas far away from forest margin while the lowest abundance was found on the farms close to UDF. However, the richness and abundance of trees that are found in coffee farms, most of which are fruit trees, are not significantly different in the three forest proximity categories (far from forest, close to UDF, close to DF). Further, the dominance of fruit and short rotation trees may be influenced by the tree and land tenure system in the study area.

These results demonstrate that regardless of the distance from the nearest natural forest and forest exploitation history, the most important source of tree cover in coffee farms is from introduced multipurpose or fruit trees as opposed to indigenous trees from neighbouring forests. $F$. natalensis, the only indigenous tree species that is reasonably abundant in coffee farms, is usually planted in this part of Uganda for production of bark cloth which is very popular in traditional rituals and ceremonies.

\section{Acknowledgements}

We thank Uganda's National Union of Coffee Agribusiness and Farm Enterprises (NUCAFE) and the National Forestry Resources Research Institute of Uganda (NaFORRI) for logistical support. We are very grateful to the local leaders in the study area and in particular Fritz Plattner, Ernest Bbongole, Hajjat Madina Kasozi and Raphel Bizimungu for working with us throughout the study period. We are also indebted to the great contribution of our technicians Mr Richard Akope (RIP) and Mr Juma Kaweesa Mukasa during data collection. Finally, we are very grateful to all the farmers who allowed us to work on their farms.

\section{Disclosure statement}

No potential conflict of interest was reported by the authors.

\section{Funding}

We are grateful to the European Union (EU) Programme on Environment in Developing Countries for funding this study through the CAFNET (Connecting, enhancing and sustaining environmental services and market values of coffee agroforestry in Central America, East Africa and India) project (EuropAid 
ENV/2006/114-382/TPS) which was coordinated by the Centre de Coopération Internationale en Recherche Agronomique pour le Développement (CIRAD) and World Agroforestry Centre (ICRAF).

\section{Supplemental data}

Supplemental data for this article can be accessed at http://dx.doi. org/10.1080/21513732.2015.1050607.

\section{References}

Abebe T. 2005. Diversity in homegarden agroforestry systems of Southern Ethiopia [PhD thesis]. Wageningen: Wageningen University.

Albertin A, Nair PKR. 2004. Farmers perspectives on the role of shade trees in coffee production systems: an assessment from Nicoya Peninsula, Costa Rica. Hum Ecol. 32:443-463. doi:10.1023/B:HUEC.0000043515.84334.76

Arnold JEM. 1997. Framing the issues. In: Arnold JEM, Dewers PA, eds. Farms, trees and farmers: responses to agricultural intensification. London (UK): Earthscan Publications; p. 3-20.

Balihuta AM, Sen K 2001. Macroeconomic policies and rural livelihood diversification: a Ugandan case study. LADDER Working Paper No. 3. Kampala (Uganda).

Bandeira FP, Martorell C, Meave JA, Caballero J. 2005. The role of rustic coffee plantations in the conservation of wild tree diversity in the Chinantec region of Mexico. Biodivers Conserv. 14:1225-1240. doi:10.1007/s10531-004-7843-2

Banks JE, Hannon L, Hanson P, Dietsch T, Castro S, Urena N, Chandler M. 2013. Effects of proximity to forest habitat on hymenoptera diversity in a Costa Rican coffee agro-ecosystem. Pan-Pac Entomol. 89:60-68. doi:10.3956/2012-28.1

Baranga D. 2007. Observations on resource use in Mabira Forest Reserve, Uganda. Afr J Ecol. 45:2-6. doi:10.1111/j.13652028.2007.00729.x

Beer J, Muschler R, Kass D, Somarriba E. 1997. Shade management in coffee and cacao plantations. Agrofor Syst. 38:139-164. doi:10.1023/A:1005956528316

Boffa JM, Kindt R, Katumba BM, Jourget JG, Turyomurugyendo L. 2008. Management of tree diversity in agricultural landscapes around Mabira Forest Reserve, Uganda. Afr J Ecol. 46:24-32. doi:10.1111/j.1365-2028.2008.00926.x

Boffa JM, Turyomurugyendo L, Barnekow-Lillesø JP, Kindt R. 2005. Enhancing farm tree diversity as a means of conserving landscape-based biodiversity: insights from the Kigezi highlands, S W Uganda. Mt Res Dev. 25:212-217. doi:10.1659/0276-4741(2005)025[0212:EFTDAA]2.0.CO;2

Bolwig S, Pomeroy D, Tushabe D. 2006. Crops, trees, and birds: biodiversity change under agricultural intensification in Uganda's farmed landscapes. Dan J Geog. 106:115-130. doi:10.1080/00167223.2006.10649561

Bote AD, Struik PC. 2011. Effects of shade on growth, production and quality of coffee (Coffea arabica) in Ethiopia. J Hort For. 3:336-341.

Correia M, Diabaté M, Béavogui P, Guilavogui K, Lamanda N, De Foresta H. 2010. Conserving forest tree diversity in Guinée Forestière (Guinea, West Africa): the role of coffeebased agroforests. Biodivers Conserv. 19:1725-1747. doi:10.1007/s10531-010-9800-6

DaMatta FM, Ramalho JDC. 2006. Impacts of drought and temperature stress on coffee physiology and production: a review. Braz J Plant Physiol. 18:55-81. doi:10.1590/S167704202006000100006

DaMatta FM, Ronchi CP, Maestri M, Barros RS. 2007. Ecophysiology of coffee growth and production. Braz J Plant Physiol. 19:485-510. doi:10.1590/S167704202007000400014
Davenport T, Howard P, Baltzer M. 1996. Mabira Forest Reserve: biodiversity report. Kampala: Forest Department.

Escalante E. 1995. Coffee and agroforestry in Venezuela. Agrofor Today. 7:5-7.

Gobin A, Campling P, Feyen J. 2001. Logistic modelling to identify and monitor local land management systems. Agrofor Syst. 67:1-20. doi:10.1016/S0308-521X(00)00043-3

Hammer O, Harper DAT, Ryan PD. 2001. PAST: palaeontological Statistics software package for education and data analysis. Palaeo Electr. 4:9.

Hernández-Martínez G, Manson RH, Hernández AC. 2009. Quantitative classification of coffee agroecosystems spanning a range of production intensities in central Veracruz, Mexico. Agric Ecosyst Environ. 134:89-98. doi:10.1016/j. agee.2009.05.020

International Coffee Council. 2014. World coffee trade (19632013): a review of the markets, challenges and opportunities facing the sector. A Report of the International Coffee Council 112th Session; 3-7 March; London (UK).

Ipulet P, Kasenene J. 2008. Diversity of genus Ficus L. (Moraceae) in farmlands and pastoral areas in Buganda region, central Uganda. Afr J Ecol. 46:52-58. doi:10.1111/ j.1365-2028.2008.00929.x

Isabirye M, Verbist B, Magunda MK, Poesen J, Deckers J. 2008. Tree density and biomass assessment in agricultural systems around Lake Victoria, Uganda. Afr J Ecol. 46:59-65. doi:10.1111/j.1365-2028.2008.00930.x

Jost L. 2007. Partitioning diversity into independent alpha and beta components. Ecol. 88:2427-2439. doi:10.1890/06-1736.1

Kamanyire M. 2000. Sustainability indicators for natural resource management and policy: natural resource management and policy in Uganda - Overview Paper. Working Paper 3. Kampala: Economic Policy Research Centre, Makerere University.

Kasolo WK, Temu AB. 2008. Tree species selection for buffer zone agroforestry: the case of Budongo forest in Uganda. Int For Rev. 10:52-64.

Katumba BM, Boffa JM, Abigaba G, Okorio J. 2004. Domestication of medicinal tree species in the Victoria lakeshore region. Ug J Agric Sci. 9:84-88.

Kigula J. 1993. Land disputes in Uganda: an overview of the types of land disputes and the dispute settlement fora. Kampala: Makerere Institute of Social Research (MISR), Makerere University.

Kindt R, Coe R. 2005. Tree diversity analysis. A manual and software for common statistical methods for ecological and biodiversity studies. Nairobi: World Agroforestry Centre (ICRAF.

Kiyingi I, Gwali S. 2012. Productivity and profitability of Robusta coffee agroforestry systems in central Uganda. Uganda J Agric Sci. 13:85-93.

Legendre P, Borcard D, Peres-Neto PR. 2005. Analyzing beta diversity: partitioning the spatial variation of community composition data. Ecol Monogr. 75:435-450.

Lock CGW. 1888. Coffee: its culture and commerce in all countries. London (UK): E. \& F.N. Spon.

Masiga M, Ruhweza A. 2007. Commodity revenue management: coffee and cotton in Uganda. Winnipeg (Canada): International Institute for Sustainable Development (IISD.

Méndez VE, Bacon CM. 2006. Ecological processes and farmer livelihoods in shaded coffee production. Leisa Magazine. 22:22-23.

Méndez VE, Gliessman SR, Gilbert GS. 2007. Tree biodiversity in farmer cooperatives of a shade coffee landscape in western El Salvador. Agric Ecosyst Environ. 119:145-159. doi:10.1016/j.agee.2006.07.004

Moorhead LC, Philpott SM, Bichier P. 2010. Epiphyte biodiversity in the coffee agricultural matrix: canopy stratification and distance from forest fragments. Conserv Biol. 24:737-746. doi:10.1111/j.1523-1739.2009.01430.x 
Muschler R. 2001. Shade improves coffee quality in a sub-optimal coffee-zone of Costa Rica. Agrofor Syst. 51:131-139. doi:10.1023/A:1010603320653

Muschler RG, Bonnemann A. 1997. Potentials and limitations of agroforestry for changing land-use in the tropics: experiences from Central America. For Manag. 91:61-73. doi:10.1016/ S0378-1127(96)03887-X

NEMA. 1997. District State of the Environment Report, Mukono. Kampala: National Environment Management Authority.

Peeters LYK, Soto-Pinto L, Perales H, Montoya G, Ishiki M. 2003. Coffee production, timber, and firewood in traditional and Inga-shaded plantations in Southern Mexico. Agr Ecosyst Environ. 95:481-493. doi:10.1016/S0167-8809(02) 00204-9

Perfecto I, Rice RA, Greenberg R, Van Der Voort ME. 1996. Shade coffee: a disappearing refuge for biodiversity. Bioscience. 46:598-608. doi:10.2307/1312989

Perfecto I, Vandermeer J. 2002. Quality of agroecological matrix in a tropical montane landscape: ants in coffee plantations in southern Mexico. Conserv Biol. 16:174-182. doi:10.1046/ j.1523-1739.2002.99536.x

Perfecto I, Vandermeer J, Mas AH, Pinto LS. 2005. Biodiversity, yield, and shade coffee certification. Ecol Econ. 54:435-446. doi:10.1016/j.ecolecon.2004.10.009

Place F, Otsuka K 2000. The role of tenure in the management of trees at the community level: theoretical and empirical analyses from Uganda and Malawi. CAPRi Working Paper No. 9. Washington (DC): International Food Policy Research Institute (IFPRI).

Pohlan HAJ, Janssens MJJ. 2012. Growth and production of coffee. Soil Plant Growth Crop Prod. 3:1-11.

Rice RA. 2008. Agricultural intensification within agroforestry: the case of coffee and wood products. Agr Ecosyst Environ. 128:212-218. doi:10.1016/j.agee.2008.06.007

Ricketts TH. 2004. Tropical forest fragments enhance pollinator activity in nearby coffee crops. Conserv Biol. 18:1262-1271. doi:10.1111/j.1523-1739.2004.00227.x

Ricketts TH, Daily GC, Ehrlich PR, Fay JP. 2001. Countryside biogeography of moths in a fragmented landscape: biodiversity in native and agricultural habitats. Conserv Biol. 15:378-388. doi:10.1046/j.1523-1739.2001.015002378.x

Sanchez G, Kass D, Borel R, Bonnemann A, Beer J. 1988. Shade trees in plantation culture. In: Moore E, ed. Agroforestry land-use Systems: proceedings of a Special Session of
Agroforestry Land-Use Systems in International Agronomy. Aneheim (CA): Funny Press; American Society of Agronomy Annual Meeting; p. 75-83.

Sebukyu VB, Mosango DM. 2012. Adoption of agroforestry systems by farmers in Masaka district of Uganda. Ethnobot Res Appl. 10:59-68.

Snoeck D, Zapata F, Domenach A. 2000. Isotopic evidence of the transfer of nitrogen fixed by legumes to coffee trees. Biotechnol Agron Soc Environ. 4:95-100.

Soto-Pinto L, Perfecto I, Castillo-Hernandez J, Caballero-Nieto J. 2000. Shade effect on coffee production at the northern Tzeltal zone of the state of Chiapas, Mexico. Agric Ecosyst Environ. 80:61-69. doi:10.1016/S0167-8809 (00)00134-1

Soto-Pinto L, Villalvazo-Lopez V, Jimenez-Ferrer G, RamirezMarcial N, Montoya G, Sinclair FL. 2007. The role of local knowledge in determining shade composition of multistrata coffee systems in Chiapas, Mexico. Biodivers Conserv. 16:419-436.

Terborgh J, Pitman N, Silman M, Schichter H, Nunez PV. 2002. Maintenance of tree diversity in tropical forests. In: Levey DJ, Silva WR, Galetti M, eds. Seed dispersal and frugivory: ecology, evolution and conservation. New York (NY): CABI International.

Tuomisto H, Ruokolainen K. 2006. Analyzing or explaining beta diversity? Understanding the targets of different methods of analysis. Ecol. 87:2697-2708.

Vaast P, Bertrand B, Perriot -J-J, Guyot B, Génard M. 2006. Fruit thinning and shade improve bean characteristics and beverage quality of coffee (Coffea arabica L.) under optimal conditions. J Sci Food Agric. 86:197-204. doi:10.1002/ (ISSN)1097-0010

Vaast P, van Kanten R, Siles P, Dzib B, Franck N, Harmand JM, Genard M. 2005. Shade: a key factor for coffee sustainability and quality. In: Proceedings of the 20th ASIC Colloquium, Bangalore. Paris: ASIC; p. 887-896.

Williams-Linera G. 2002. Tree species richness complementarity, disturbance and fragmentation in a Mexican tropical montane cloud forest. Biodivers Conserv. 11:1825-1843. doi:10.1023/ A:1020346519085

Zuur AK, Ieno EN, Smith GM. 2007. Analysing ecological data. New York (NY): Springer Science + Business Media, LLC. 